ISSN 1392-3196 / e-ISSN 2335-8947

Zemdirbyste-Agriculture, vol. 106, No. 1 (2019), p. 59-64

DOI 10.13080/z-a.2019.106.008

\title{
The use of rice polish medium for the evaluation of antifungal activity of lactic acid bacteria
}

\author{
Rūta VAITKEVIČIENE ${ }^{1}$, Daiva ŽADEIKE் ${ }^{1}$, Elena BARTKIENÉ2 ${ }^{2}$, Vita KRUNGLEVIČIŪTÉ ${ }^{2}$, \\ Violeta BALIUKONIENE ${ }^{2}$, Skaidre SUPRONIENE ${ }^{3}$, Gražina JUODEIKIENE ${ }^{1}$ \\ ${ }^{1}$ Kaunas University of Technology \\ Radvilènų 19, Kaunas, Lithuania \\ E-mail: ruta.vaitkeviciene@ktu.lt \\ ${ }^{2}$ Lithuanian University of Health Science \\ Tilžès 18, Kaunas, Lithuania \\ ${ }^{3}$ Institute of Agriculture, Lithuanian Research Centre for Agriculture and Forestry \\ Instituto 1, Akademija, Kedainiai distr., Lithuania
}

\begin{abstract}
The aim of this study was to evaluate rice polish as a substrate for the production of metabolites characterised by antifungal activity by using lactic acid bacteria. The Lactobacillus plantarum, L. brevis, L. paracasei, L. uvarum, L. farraginis, Pediococcus pentosaceus and P. acidilactici strains were tested in the experiment. The antifungal activity of the strains was evaluated against filamentous fungi, such as Aspergillus versicolor, A. terreus, A. niger, A. fumigatus and Penicillium spinulosum, P. viridicatum, P. palitans. The rice polish fermentation was carried out in a single step without growth supplementation at submerged fermentation conditions. The obtained results confirmed that rice polish is a suitable substrate for the production of antifungal metabolites depending on lactic acid bacteria (LAB) strain. The tested $P$. pentosaceus strains showed strong and moderate inhibitory activity against $P$. viridicatum, $A$. versicolor fungi, while $P$. acidilactici strains showed moderate and low activity against Aspergillus sp. fungi. None of the tested LAB exhibited antifungal activity against $A$. terreus and $A$. niger.
\end{abstract}

Key words: antifungal activity, Aspergillus, lactobacilli, pediococci, Penicillium, rice bran.

\section{Introduction}

The widespread fungi are important contaminants of food crops, food raw materials and processed foods. Fungal contamination causes not only substantial economic losses, but also food safety issues (Hawksworth, 2001). Prevention and control of fungal contamination is an important problem in the field of agriculture and industry. In food industry, chemical preservatives are generally used to control the growth and reproduction of fungi. However, due to abuse of chemical preservatives, their residues and food safety issues become more and more important. Also, consumer demand for safe food with a long shelf life and preference for minimally processed products that do not contain chemical preservatives make it more challenging for food processing (Cotter et al., 2005). The use of microorganisms to prevent fungal contamination has been gaining interest during the recent years as they can mitigate the adverse effects of chemical preservatives (Prema et al., 2010). Antifungal peptides are reported to be one of the most important natural preservatives which are effective against most of the fungal pathogens. According to the literature, most strains of Bacillus sp. produced only one or two antimicrobial substances (Mora et al., 2011). Lactic acid bacteria can provide different kinds of bioactive molecules, such as organic acids, fatty acids, hydrogen peroxide and bacteriocins (Asmahan, 2010; Schnurer, Magnusson, 2005). Recently, several antimicrobials have been discovered; however, it has become imperative to search for more stable antimicrobials with a broad range of activities, especially against various spoilage moulds

The ability to produce several antibacterial and antifungal substances confers biopreservation potential to lactic acid bacteria (Cabo et al., 2002; Cheong et al., 2014). The lactic acid bacteria have been used as biopreservative organisms in food and feed systems. They are Gram-positive bacteria and include species of the genera Enterococcus, Lactobacillus, Leuconostoc, Lactococcus

Please use the following format when citing the article:

Vaitkevičienė R., Žadeikė D., Bartkienė E., Krunglevičiūtė V., Baliukonienė V., Supronienė S., Juodeikienè G. 2019. The use of rice polish medium for the evaluation of antifungal activity of lactic acid bacteria. Zemdirbyste-Agriculture, 106 (1): $59-64$. DOI $10.13080 / \mathrm{z}-\mathrm{a} .2019 .106 .008$ 
and Pediococcus. For centuries, fermentation with lactic acid microorganisms has been a simple and inexpensive method to improve the functional value and safety of foods. The production of inhibitory substances and organic acids by the $\mathrm{LAB}$ is an indicator that these bacteria could be widely used in the food industry as biopreservatives due to their broad inhibition spectrum.

Antifungal metabolite production by lactic acid bacteria using natural by-products from food production is a very promising area. Rice polish contains various nutrients, such as protein, fat, carbohydrates, minerals, and vitamins, making it a beneficial food source. The ability to produce several antibacterial and antifungal substances confers biopreservation potential to lactic acid bacteria. Using alternative biotechnology tools for the evaluation of antimicrobial activity against undesirable microorganisms in the food industry specific metabolites would be suitable candidates for use as antimicrobial agents.

The aim of this study was to analyse the potential of brown rice polishing waste as a substrate for antifungal metabolite production by lactic acid bacteria (LAB) newly isolated from cereal based sourdoughs.

\section{Materials and methods}

Materials and microorganisms. Rice polish (moisture $11.38 \mathrm{~g} 100 \mathrm{~g}^{-1}$, protein $11.05 \mathrm{~g} 100 \mathrm{~g}^{-1}$,

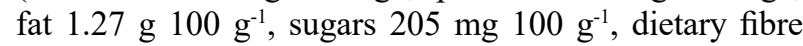

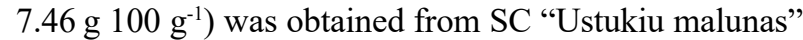
(Pasvalys, Lithuania) after processing of brown rice. Before analysis, rice polish was ground in a laboratory mill (Buhler Bros Inc., Switzerland) and sterilized at $121^{\circ} \mathrm{C}$ for $15 \mathrm{~min}$. Eleven lactic acid bacteria (LAB): Lactobacillus paracasei LUHS244 (NBRC 15889), Lactobacillus uvarum LUHS245 (strain 8), Lactobacillus farraginis LUHS206 (NRIC 0676), Lactobacillus brevis LUHS140, LUHS173 (ATCC 367; n = 2), Lactobacillus plantarum LUHS18 (WCFS1), Lactobacillus plantarum LUHS135 (JCM 1149), Pediococcus acidilactici LUHS29, LUHS236 (DSM 20284; n = 2), Pediococcus pentosaceus LUHS22, LUHS100 (ATCC 25745; $\mathrm{n}=2$ ), previously isolated from a spontaneously fermented cereal based media and identified by phenotypic and molecular techniques (Bartkiene et al., 2017), were used in this study during 2016-2018. For the experiment, each strain was cultured in an MRS (de Man, Rogosa and Sharpe) broth CM0359 (Oxoid Ltd., UK) for $48 \mathrm{~h}$ at $30^{\circ} \mathrm{C}$ in the dark.

Rice polish fermentation. For fermentation assay, the rice polish sample $(40 \pm 0.01 \mathrm{~g})$ was mixed with the distilled water $(60 \mathrm{~mL})$ wherein $2 \%(\mathrm{w} / \mathrm{v})$ of the freshly prepared culture of each LAB strain was added. The samples were incubated for $72 \mathrm{~h}$ at $30^{\circ} \mathrm{C}$ in the dark. The acidity characteristics ( $\mathrm{pH}$ values) were evaluated after 24, 48 and $72 \mathrm{~h}$ of fermentation; the antifungal activity was evaluated after $48 \mathrm{~h}$ of fermentation.

Determination of acidity $(\mathrm{pH})$. The $\mathrm{pH}$ values of nutritional (MRS) and rice polish (RPL) media after fermentation by different lactic acid bacteria were measured and recorded by a $\mathrm{pH}$ electrode (Sartorius, Germany). The $\mathrm{pH}$ value was determined for a $10 \mathrm{~g}$ sample of sourdough homogenized with $90 \mathrm{~mL}$ of distilled water, filtrated and measured. All analyses were performed in duplicate.
Preparation of concentrated culture filtrate. LAB strains were propagated for $24 \mathrm{~h}$ in MRS (Oxoid Ltd.) nutritional medium at optimal temperature $\left(30-45^{\circ} \mathrm{C}\right)$. The cells were harvested by centrifugation $\left(4500 \mathrm{~g}, 20 \mathrm{~min}, 5^{\circ} \mathrm{C}\right)$, whereas the supernatant was filtered using a $0.22 \mu \mathrm{m}$ sterile membrane filter (Merck, Germany) and separated into two subsamples. The $\mathrm{pH}$ value of one subsample was adjusted to 6.5 with $5 \mathrm{~mol} \mathrm{~L}^{-1}$ $\mathrm{NaOH}$ to eliminate the effect of organic acids. Fermented rice polish also was harvested by centrifugation and separated into two subsamples, one of them had pH 6.5.

Antifungal assay. The plant pathogenic fungal strains of Penicillium spp., Aspergillus spp. (Table 1) were cultured on sabouraud dextrose agar (SDA) (Oxoid Ltd.) (per $1 \mathrm{~L}: 10 \mathrm{~g}$ peptone, $40 \mathrm{~g}$ glucose and $15 \mathrm{~g}$ agar) plates using aseptic procedures to avoid contamination. Conidia from fungal mycelium were obtained from 7-dayold SDA cultures of the fungus incubated at $25-30^{\circ} \mathrm{C}$ in the dark and then stored at $5^{\circ} \mathrm{C}$. A spore suspension was collected after 7 days by vigorously shaking the slants with sterile peptone water. Spore concentrations were then adjusted to $1 \times 10^{6}$ spores $\mathrm{mL}^{-1}$ in half-strength using a Neubauer Chamber cell counting method (Paudel, Tyagi, 2014).

Table 1. Fungal strains* and their optimal temperature

\begin{tabular}{ll}
\hline \multicolumn{1}{c}{ Fungal strain } & Optimal temperature \\
\hline Penicillium viridicatum & $25^{\circ} \mathrm{C}$ \\
Penicillium spinulosum & $25^{\circ} \mathrm{C}$ \\
Penicillium palitans & $25^{\circ} \mathrm{C}$ \\
Aspergillus terreus & $35-40^{\circ} \mathrm{C}$ \\
Aspergillus niger & $25^{\circ} \mathrm{C}$ \\
Aspergilus versicolor & $22-26^{\circ} \mathrm{C}$ \\
Aspergillus fumigatus & $25^{\circ} \mathrm{C}$ \\
\hline
\end{tabular}

* - growth on sabouraud dextrose agar (Samson, 2000)

Determination of antifungal activity. The antifungal activity of the strains was measured using an agar well diffusion method (Magaldi et al., 2004) and disk-diffusion method (Balouiri et al., 2015). For the assay, the SDA $(25 \mathrm{ml})$ cooled to $45^{\circ} \mathrm{C}$ was poured into Petri dish and overlaid with $100 \mu \mathrm{L}$ of fungal suspension. For agar well diffusion method, the antifungal activity against fungi was determined by measuring the inhibition zones ( $\mathrm{mm})$. The LAB culture suspension $(100 \mu \mathrm{L})$ after centrifugation $(4500 \times \mathrm{rpm}, 20$ $\mathrm{min}$ ) was added to each well ( $6 \mathrm{~mm}$ in diameter) punched in the cooled agar plates following the incubation for $48 \mathrm{~h}$ at the $25^{\circ} \mathrm{C}$. After the inhibition zones $(\mathrm{mm})$ had been measured, the antifungal activity was recorded according to the following scale (Manini et al., 2016): $(-)$ no inhibition, $(+)$ delay of spore formation (1-3 mm), $(++)$ delay of spore formation with a small clear zone of inhibition (3-6 mm), (+++) a very good inhibition of mycelium growth and sporulation with large clear zones $(>6 \mathrm{~mm})$ around the punched well. For agar diskdiffusion method, the antifungal activity against fungi was determined by measuring the inhibition zones ( $\mathrm{mm})$ formed around each disk. Sterile filter paper disks $6 \mathrm{~mm}$ diameter (Oxoid Ltd.) impregnated with $100 \mu$ of LAB culture suspension were placed on the inoculated agar surfaces. All tests were performed in duplicate, and the 
diameters of the growth inhibition zones around each disk were measured (in $\mathrm{mm}$ ) after incubation at $25^{\circ} \mathrm{C}$ for $48 \mathrm{~h}$.

\section{Results and discussion}

Changes in acidity (ph) during rice polish fermentation by the tested lactic acid bacteria (LAB). The higher acidification rate of rice polish medium was achieved by fermentation with lactobacilli compared to pediococci. The highest $\mathrm{pH}$ values were of the medium fermented with $L$. brevis strains ( $\mathrm{pH}=3.26$ for LUHS140, $\mathrm{pH}=3.38$ for LUHS173) after $48 \mathrm{~h}$ of fermentation. The lowest $\mathrm{pH}$ values were of the samples fermented with P. acidilactici strains LUHS29 $(\mathrm{pH}=3.76)$ and LUHS236 $(\mathrm{pH}=3.88)$ (Fig. 1). According to the obtained results, the more intensive production of organic acids by the tested LAB was noticed in rice polish medium compared to nutritional medium (MRS), the $\mathrm{pH}$ values of rice polish samples fermented with lactobacilli and pediococci were by $\mathrm{pH} 3.58$ and by $15.76 \%$ lower on average than those of MRS samples.

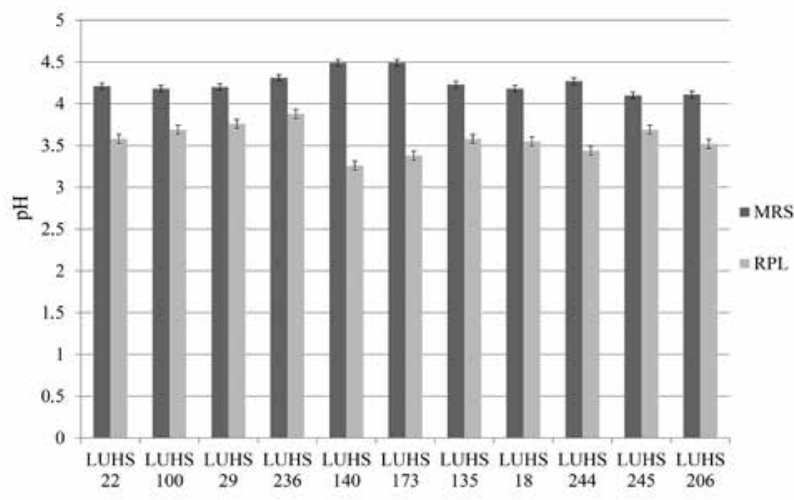

LUHS22, LUHS100 - Pediococcus pentosaceus, LUHS29, LUHS236 - $P$. acidilactici; LUHS140, LUHS173 Lactobacillus brevis, LUHS135, LUHS18 - L. plantarum, LUHS244 - L. paracasei, LUHS245 - L. uvarum, LUHS206 - L. farraginis

Figure 1. The acidity $(\mathrm{pH})$ values of nutritional (MRS) and rice polish (RPL) media after $48 \mathrm{~h}$ fermentation by different lactic acid bacteria

The highest acidity in rice polish medium was shown by five strains of all the LAB tested. As is seen from Figure 2, the highest acidity and the lowest $\mathrm{pH}$ values were produced by the LUHS100 (pH 3.80) after $24 \mathrm{~h}$ fermentation, following the LUHS206 ( $\mathrm{pH} 3.79)$. The highest acidity was determined in rice medium fermented by LUHS173 (pH 3.38) and LUHS206 (pH 3.52 ) after $48 \mathrm{~h}$ fermentation, and in samples fermented by LUHS100 (pH 2.64) and LUHS236 (pH 2.84) after $72 \mathrm{~h}$ of fermentation. The drastic decrease in $\mathrm{pH}$ during $72 \mathrm{~h}$ fermentation was shown by the LUHS173 $(36.90 \%)$ and LUHS29 (34.09\%), LUHS236 (33.49\%) (Fig. 2).

Lactic acid bacteria are able to produce different kind of bioactive molecules, such as organic acids, fatty acids, hydrogen peroxide and bacteriocins (Gerez et al., 2009), equally to produce other small compounds with a low molecular weight during fermentation processes (Cizeikiene et al., 2013), also provide metabolites that can inhibit the growth of fungi under the native conditions

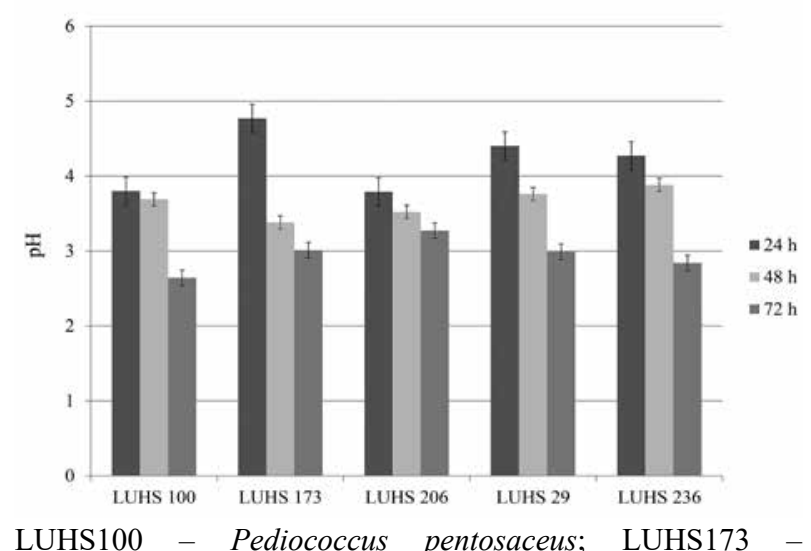

Lactobacillus brevis, LUHS206 - L. farraginis, LUHS29, LUHS236 - P. acidilactici

Figure 2. Changes in the acidity $(\mathrm{pH})$ of medium during fermentation of rice polish by selected lactic acid bacteria

(Hassan, Bullerman, 2008). According to the literature, the acetic acid and the lactic acid produced was likely the primary factor responsible for the Lactobacillus antimicrobial properties (Cabo et al., 2002). Also, it was reported that $P$. pentosaceus produced three antifungal substances: cyclo(L-Phe-L-Pro), cyclo(L-Phe-trans-4OH-L-Pro) and phenyllactic acid (Magnusson et al., 2003).

Antifungal activity of tested $L A B$ in rice polish medium determined by agar well diffusion assay. According to the results, rice polish substrate showed the potential for production of antifungal metabolites by the tested LAB. The tested LAB strains showed different inhibition capability on the growth of Penicillium and Aspergillus sp. strains (Table 2). Lactobacillus strains showed strong and moderate activity against Penicillium sp., while Pediococcus strains showed moderate and low activity against Aspergillus sp.

From the tested LAB, $P$. acidilactici LUHS236 and L. faraginis LUHS206, strains were shown to moderate inhibition and delay of spore formation against $P$. spinulosum. The $P$. pentosaceus LUHS100 and L. brevis LUHS173 produced the high $(++)$ antifungal activity against $A$. versicolor strain. Among other tested LAB, only L. plantarum LUHS18 initiated the delay of fungal sporulation $(+)$ against $P$. viridicatum, as well as $P$. acidilactici LUHS29 and lactobacilli LUHS173, LUHS244 and LUHS245 delayed fungal sporulation (+) against $P$. spinulosum. The $P$. acidilactici LUHS29, LUHS236, P. pentosaceus LUHS22, L. brevis LUHS173 and L. uvarum LUHS245 were slightly active $(+)$ against $P$. palitans. From the tested strains, $P$. pentosaceus LUHS100 and L. brevis LUHS173 were able to inhibit A. fumigatus and L. brevis LUHS173 was able to inhibit A. versicolor. The others LAB (LUHS140, LUHS135 and LUHS206) did not form the inhibition zones (Table 2).

In previous studies, $P$. acidilactici was found to inhibit the growth of fungi, including species of Aspergillus and Penicillium spp. (Mandal et al., 2013). $P$. pentosaceus and $P$. acidilactici strains have been shown to inhibit the growth and sporulation of the $A$. niger (Cizeikiene et al., 2013). Also, the supernatant of $P$. pentosaceus and $P$. acidilactici strains showed the high antifungal activity against $A$. versicolor strain (Juodeikiene et al., 2016). 
Table 2. The antifungal activity of lactic acid bacteria (LAB) supernatants against the Penicillium and Aspergillius sp. (an agar well diffusion method)

\begin{tabular}{|c|c|c|c|c|c|c|c|c|c|c|c|c|}
\hline \multirow{3}{*}{$\begin{array}{c}\text { Micro- } \\
\text { organisms }\end{array}$} & \multirow{3}{*}{ Medium } & \multicolumn{2}{|c|}{ P. pentosaceus } & \multicolumn{2}{|c|}{ P. acidilactici } & \multicolumn{2}{|c|}{ L. brevis } & \multicolumn{2}{|c|}{ L. plantarum } & \multirow{2}{*}{$\frac{\text { L. paracasei }}{\text { LUHS }}$} & \multirow{2}{*}{$\frac{\text { L. uvarum }}{\text { LUHS }}$} & \multirow{2}{*}{$\frac{\text { L. farraginis }}{\text { LUHS }}$} \\
\hline & & LUHS & LUHS & LUHS & LUHS & LUHS & LUHS & LUHS & LUHS & & & \\
\hline & & 22 & 100 & 29 & 236 & 140 & 173 & 135 & 18 & 244 & 245 & 206 \\
\hline \multirow{2}{*}{ P. viridicatum } & MRS & ++ & ++ & + & ++ & + & + & + & + & + & ++ & + \\
\hline & RPL & - & - & - & - & - & - & - & + & - & - & - \\
\hline \multirow{2}{*}{ P. spinulosum } & MRS & - & - & + & ++ & - & + & - & - & + & + & ++ \\
\hline & RPL & - & - & + & ++ & - & + & - & - & + & + & ++ \\
\hline \multirow{2}{*}{ P. palitans } & MRS & + & + & - & + & - & + & + & + & - & + & - \\
\hline & RPL & + & - & - & + & - & + & - & + & - & + & - \\
\hline \multirow{2}{*}{ A. terreus } & MRS & - & - & - & - & - & - & - & - & - & - & - \\
\hline & $\mathrm{RPL}$ & - & - & - & - & - & - & - & - & - & - & - \\
\hline \multirow{2}{*}{ A. versicolor } & MRS & + & ++ & + & + & + & ++ & + & + & + & + & + \\
\hline & RPL & - & ++ & - & - & - & ++ & - & + & - & - & - \\
\hline \multirow{2}{*}{ A. niger } & MRS & - & - & - & - & - & - & - & - & - & - & - \\
\hline & RPL & - & - & - & - & - & - & - & - & - & - & - \\
\hline \multirow{2}{*}{ A. fumigatus } & MRS & + & + & + & - & - & + & - & + & + & - & + \\
\hline & RPL & - & + & - & - & - & + & - & - & - & - & - \\
\hline
\end{tabular}

Note. MRS - nutritional medium, RPL - rice polish medium; interpretation of zone diameter of inhibition: $(-)=$ no inhibition, $(+)$ $=$ delay of spore formation $(1-3 \mathrm{~mm}),(++)=$ delay of spore formation with a small clear zone of inhibition around the punched well $(3-6 \mathrm{~mm}),(+++)=$ a very good inhibition of mycelium growth and sporulation with large clear zones around the punched well ( $>6 \mathrm{~mm})$.

As the low acidity $(\mathrm{pH})$ has always been associated with antifungal activity (Cabo et al., 2002), the antifungal activity assay was repeated by analysing neutralized LAB supernatants.

Neutralised LAB rice polish supernatants (Table 3) showed lower antifungal activity compared to that of not neutralised (Table 3 ). The delay of fungal sporulation $(+)$ was shown against the $P$. spinulosum by four LAB strains, against the $P$. viridicatum by three LAB strains, against the $P$. palitans by only one strain. Regarding Aspergillus sp., the delay of fungal sporulation $(+)$ was shown against $A$. versicolor and A. fumigatum by five LAB strains. The pediococci LUHS100, LUHS29 and L. brevis LUHS173 were slightly active $(+)$ against $2-3$ pathogens, the other LAB did not form the inhibition zones.

Table 3. The antifungal activity of neutralised (pH 6.5) lactic acid bacteria (LAB) supernatants against the Penicillium and Aspergillus sp. (an agar well diffusion method)

\begin{tabular}{|c|c|c|c|c|c|c|c|c|c|c|c|c|}
\hline \multirow{2}{*}{$\begin{array}{c}\text { Micro- } \\
\text { organisms }\end{array}$} & \multirow[b]{2}{*}{ Medium } & \multicolumn{2}{|c|}{ P. pentosaceus } & \multicolumn{2}{|c|}{ P. acidilactici } & \multicolumn{2}{|c|}{ L. brevis } & \multicolumn{2}{|c|}{ L. plantarum } & \multirow{2}{*}{$\frac{\text { L. paracasei }}{\text { LUHS }}$} & \multirow{2}{*}{$\begin{array}{c}\text { L. uvarum } \\
\text { LUHS } \\
245\end{array}$} & \multirow{2}{*}{$\begin{array}{c}\text { L. farraginis } \\
\text { LUHS } \\
206\end{array}$} \\
\hline & & $\begin{array}{c}\text { LUHS } \\
22\end{array}$ & $\begin{array}{c}\text { LUHS } \\
100\end{array}$ & $\begin{array}{c}\text { LUHS } \\
29\end{array}$ & $\begin{array}{c}\text { LUHS } \\
236\end{array}$ & $\begin{array}{c}\text { LUHS } \\
140\end{array}$ & $\begin{array}{c}\text { LUHS } \\
173\end{array}$ & $\begin{array}{c}\text { LUHS } \\
135\end{array}$ & $\begin{array}{c}\text { LUHS } \\
18\end{array}$ & & & \\
\hline \multirow{2}{*}{ P. viridicatum } & MRS & + & - & - & - & - & + & + & + & + & + & - \\
\hline & RPL & - & - & - & - & - & + & + & + & - & - & - \\
\hline \multirow{2}{*}{ P. spinulosum } & MRS & - & + & + & + & - & - & - & - & + & - & - \\
\hline & RPL & - & + & + & + & - & - & - & - & + & - & - \\
\hline \multirow{2}{*}{ P. palitans } & MRS & + & - & - & - & - & - & - & - & - & - & - \\
\hline & RPL & + & - & - & - & - & - & - & - & - & - & - \\
\hline \multirow{2}{*}{ A. terreus } & MRS & - & - & - & - & - & - & - & - & - & - & - \\
\hline & RPL & - & - & - & - & - & - & - & - & - & - & - \\
\hline \multirow{2}{*}{ A. versicolor } & MRS & - & + & - & - & - & + & - & - & - & + & - \\
\hline & RPL & - & + & + & + & + & + & - & + & - & - & - \\
\hline \multirow{2}{*}{ A. niger } & MRS & - & - & - & - & - & - & - & - & - & - & - \\
\hline & RPL & - & - & - & - & - & - & - & - & - & - & - \\
\hline \multirow{2}{*}{ A. fumigatus } & MRS & + & + & + & - & - & + & - & + & + & - & + \\
\hline & RPL & - & + & + & - & + & - & + & - & + & - & - \\
\hline
\end{tabular}

Note. MRS - nutritional medium, RPL - rice polish medium; interpretation of zone diameter of inhibition: $(-)=$ no inhibition, $(+)$ $=$ delay of spore formation $(1-3 \mathrm{~mm}),(++)=$ delay of spore formation with a small clear zone of inhibition around the punched well $(3-6 \mathrm{~mm}),(+++)=$ a very good inhibition of mycelium growth and sporulation with large clear zones around the punched well $(>6 \mathrm{~mm})$.

No inhibition zones were fixed around the punched well against $P$. palitans (except LUHS22), A. terreus and A. niger. According to the literature, $P$. pentosaceus and $P$. acidilactici strains have no inhibition zones against $A$. terreus (Cizeikiene et al., 2013).
Antifungal activity of selected $L A B$ in rice polish medium determined by an agar disk-diffusion assay. For the optimization of antifungal activity production, five LAB strains (three Pediococcus strains and two Lactobacilli strains) showing the highest antifungal 
activity were tested by an agar disk-diffusion assay for antifungal activity against Penicillium spinulosum and Aspergillus versicolor. Metabolites produced by LAB in rice polish medium showed various degrees of antifungal activity after 24,48 and $72 \mathrm{~h}$ of fermentation (Table 4). According to the results, rice substrate extracts fermented by tested $\mathrm{LAB}$ showed inhibition zones varying from 1.0 to $5.0 \mathrm{~mm}$. The L. brevis LUHS173 showed the highest antifungal activity against $A$. versicolor (the inhibition zones 3 and $5 \mathrm{~mm}$, respectively) and $P$. spinulosum (inhibition zones 1.5 and $3 \mathrm{~mm}$, respectively) after 48 and $72 \mathrm{~h}$ of fermentation. The L. farraginis inhibited the growth of $P$. spinulosum (zone 4 and $5 \mathrm{~mm}$ ) after 48 and $72 \mathrm{~h}$ of fermentation.

Table 4. Antifungal activity against indicatory microorganisms produced by lactic acid bacteria (LAB) in rice polish medium (an agar disk-diffusion method)

\begin{tabular}{|c|c|c|c|c|c|c|c|}
\hline \multirow{3}{*}{ Microorganisms } & & \multicolumn{6}{|c|}{ Inhibition zones on an agar plate, $\mathrm{mm}$} \\
\hline & & \multicolumn{3}{|c|}{ Penicillium spinulosum } & \multicolumn{3}{|c|}{ Aspergillus versicolor } \\
\hline & & $24 \mathrm{~h}$ & $48 \mathrm{~h}$ & $72 \mathrm{~h}$ & $24 \mathrm{~h}$ & $48 \mathrm{~h}$ & $72 \mathrm{~h}$ \\
\hline Pediococcus pentosaceus & LUHS100 & $<1.0$ & $<1.0$ & $<1.0$ & $<1.0$ & $2.0 \pm 0.2$ & $2.0 \pm 0.2$ \\
\hline Lactobacillus brevis & LUHS173 & $1.0 \pm 0.2$ & $1.5 \pm 0.2$ & $3.0 \pm 0.2$ & $1.0 \pm 0.2$ & $3.0 \pm 0.2$ & $5.0 \pm 0.2$ \\
\hline L. farraginis & LUHS206 & $3.00 \pm 0.2$ & $4.00 \pm 0.2$ & $5.00 \pm 0.2$ & $<1.0$ & $<1.0$ & $1.0 \pm 0.2$ \\
\hline P. acidilactici & LUHS29 & $0.10 \pm 0.2$ & $0.10 \pm 0.2$ & $0.10 \pm 0.2$ & $<1.0$ & $<1.0$ & $<1.0$ \\
\hline P. acidilactici & LUHS236 & $0.20 \pm 0.2$ & $0.30 \pm 0.2$ & $0.30 \pm 0.2$ & $<1.0$ & $<1.0$ & $<1.0$ \\
\hline
\end{tabular}

According to the literature, different Lactobacillus strains producing acids were able to inhibit some species of fungi (Lavermicocca et al., 2000) thus LAB may be considered as an alternative for bio-conservation (Gerez et al., 2009). Also, it was reported that the P. acidilactici strain produced broad-spectrum antifungal compounds with fungicidal activity (Mandal et al., 2013). The observed effect of the acidity $(\mathrm{pH})$ suggested that organic acids present in the supernatants could be involved in the detected antifungal activity (Cabo et al., 2002). The results of our study indicated that the fermentation with LAB could enhance production of certain bioactive compounds in rice polish. These LAB naturally dominate in sourdough, and they prooduce metabolites that can inhibit the growth of fungi under the native conditions (Hassan et al., 2015). The selection of different LAB (or their combinations) with a wide spectrum of antifungal activities is an important issue for improving the safety of rice products in various food production.

\section{Conclusions}

1. Lactobacillus strains showed a higher acidification rate in rice polish medium compared to Pediococcus strains.

2. Rice polish medium was tested as a substrate for antifungal activity production against Penicillium and Aspergillus fungi without additional supplements. All Lactobacillus strains produced the antifungal activity against Penicillium sp., while Pediococcus strains showed low inhibitory activity against Aspergillus spp.

3 . None of the tested strains exhibited activity against the $A$. terreus and $A$. niger.

4. Given the fact that neutralized supernatants showed inhibitory activity, it can be concluded that the observed antifungal effects cannot be attributed to supernatant acidity, as long as the $\mathrm{pH}$-value was adjusted to 6.5 .

5. The further study will be focused on the optimization of culture medium based on rice polish for the production of high antimicrobial activity by tested microorganisms.

Received 16042018 Accepted 15102018

\section{References}

1. Asmahan A. A. 2010. Beneficial role of lactic acid bacteria in food preservation and human health: a review. Research Journal of Microbiology, 5: 1213-1220.

https://doi.org/10.3923/jm.2010.1213.1221

2. Balouiri M., Sadiki M., Koraichi Ibnsouda S. 2016. Methods for in vitro evaluating antimicrobial activity: a review. Journal of Pharmaceutical Analysis, 6: 71-79. https://doi.org/10.1016/j.jpha.2015.11.005

3. Bartkiene E., Bartkevics V., Pugajeva I., Krungleviciute V., Mayrhofer S., Domig K. 2017. The contribution of P. acidilactici, L. plantarum, and L. curvatus starters and L-(+)-lactic acid to the acrylamide content and quality parameters of mixed rye-wheat bread. LWT - Food Science and Technology, 80: 43-50.

https://doi.org/10.1016/j.lwt.2017.02.005

4. Cabo M. L., Braber A. F., Koenraad P. M. 2002. Apparent antifungal activity of several lactic acid bacteria against Penicillium discolour due to acetic acid in the medium. Journal of Food Protection, 65: 1309-1316. https://doi.org/10.4315/0362-028X-65.8.1309

5. Cheong Y. L. E., Sandhu A., Jayabalan J., Le T. T. K., Nhiep N. T., Ho H. T. M., Tumer M. S. 2014. Isolation of lactic acid bacteria with antifungal activity against the common cheese spoilage mould Penicillium commune and their potential as biopreservatives in cheese. Food Control, 46: 91-97.

https://doi.org/10.1016/j.foodcont.2014.05.011

6. Cizeikiene D., Juodeikiene G., Paskevicius A., Bartkiene E. 2013. Antimicrobial activity of lactic acid bacteria against pathogenic and spoilage microorganism isolated from food and their control in wheat bread. Food Control, 31 (2): 539-545.

https://doi.org/10.1016/j.foodcont.2012.12.004

7. Cotter P. D., Hill C., Ross R. P. 2005. Bacteriocins: developing innate immunity for food. Nature Reviews Microbiology, 3: 777-778.

https://doi.org/10.1038/nrmicro1273

8. Gerez C. L., Torino M. I., Rollán G., Valdez G. F. 2009. Prevention of bread mould spoilage by using lactic acid bacteria with antifungal properties. Food Control, 20 (2): 144-148. https://doi.org/10.1016/j.foodcont.2008.03.005

9. Hassan Y. I., Bullerman L. B. 2008. Antifungal activity of Lactobacillus paracasei ssp. tolerans isolated from a sourdough bread culture. International Journal of Food Microbiology, 121: 112-115.

https://doi.org/10.1016/j.ijfoodmicro.2007.11.038 
10. Hassan Y. I., Zhou T., Bullerman L. B. 2015. Sourdough lactic acid bacteria as antifungal and mycotoxincontrolling agents. Food Science and Technology International, 22 (1): 79-90.

https://doi.org/10.1177/1082013214565722

11. Hawksworth D. L. 2001. The magnitude of fungal diversity: the 1.5 million species estimate revisited. Mycological Research, 105: 1422-1432. https://doi.org/10.1017/S0953756201004725

12. Juodeikiene G., Bartkiene E., Cernauskas D., Cizeikiene D., Zadeike D., Lele V., Bartkevics V. 2016. Antifungal activity of lactic acid bacteria and their application for Fusarium mycotoxin reduction in malting wheat grains. LWT - Food Science and Technology, 89: 307-314. https://doi.org/10.1016/j.lwt.2017.10.061

13. Lavermicocca P., Valerio F., Evidente A., Lazzaroni S., Corsetti A., Gobbeti M. 2000. Purification and characterization of novel antifungal compounds from the sourdough Lactobacillus plantarum Strain 21B. Applied and Environmental Microbiology, 66: 4084-4090. https://doi.org/10.1128/AEM.66.9.4084-4090.2000

14. Magaldi S., Mata-Essayag S., Hartung de Capriles C., Perez C., Colella M. T., Olaizola C., Ontiveros Y. 2004. Well diffusion for antifungal susceptibility testing. International Journal of Infectious Diseases, 8: 39-45. https://doi.org/10.1016/j.ijid.2003.03.002

15. Magnusson J., Strom K., Roos S., Sjogren J., Schnurer J. 2003. Broad and complex antifungal activity among environmental isolates of lactic acid bacteria. FEMS Microbiology Letters, 219: 129-135. https://doi.org/10.1016/S0378-1097(02)01207-7
16. Mandal V., Sen S. K., Mandal N. C. 2013. Production and partial characterisation of an inducer-dependent novel antifungal compound(s) by Pediococcus acidilactici LAB 5. Journal of the Science of Food and Agriculture, 93 (10): 2445-2453. https://doi.org/10.1002/jsfa.6055

17. Manini F., Casiraghi M. C., Poutanen K., Brasca M., Erba D., Plumed-Ferrer C. 2016. Characterization of lactic acid bacteria isolated from wheat bran. LWT - Food Science and Technology, 66: 275-283. https://doi.org/10.1016/j.lwt.2015.10.045

18. Mora I., Cabrefiga J., Montesinos E. 2011. Antimicrobial peptide genes in Bacillus strains from plant environments. International Microbiology, 14: 213-223.

19. Paudel R., Tyagi S. 2014. Effect of different $\mathrm{pH}$ on the growth and sporulation of Fusarium oxysporum: the causal organism of wilt disease of tomato. International Journal of Basic and Applied Biology, 2: 103-106.

20. Prema P., Smila D., Palavesam A. Immanuel G. 2010. Production and characterization of an antifungal compound (3-phenyllactic acid) produced by Lactobacillus plantarum strain. Food and Bioprocess Technology, 3: 379-386. https://doi.org/10.1007/s11947-008-0127-1

21. Samson R. A. (ed.). 2004. Introduction to food- and airborne fungi. Amer Society for Microbiology.

22. Schnurer J., Magnusson J. 2005. Antifungal lactic acid bacteria as biopreservatives. Trends in Food Science and Technology, 16: 70-78. https://doi.org/10.1016/j.tifs.2004.02.014

\title{
Ryžių poliravimo atliekų panaudojimas įvertinti pieno rūgšties bakterijų priešgrybiniam aktyvumui
}

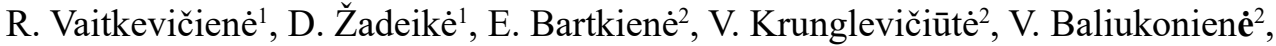 \\ S. Suproniené $\dot{e}^{3}$ G. Juodeikiené ${ }^{1}$
}

${ }^{1}$ Kauno technologijos universitetas

${ }^{2}$ Lietuvos sveikatos mokslų universitetas

${ }^{3}$ Lietuvos agrarinių ir miškų mokslų centro Žemdirbystės institutas

\section{Santrauka}

Tyrimo tikslas - ịvertinti ryžių poliravimo atliekas kaip substratą priešgrybiniu aktyvumu pasižyminčių metabolitų gamybai naudojant pieno rūgšties bakterijas. Eksperimento metu buvo naudotos Lactobacillus plantarum, L. brevis, L. paracasei, L. uvarum, L. farraginis, Pediococcus pentosaceus ir P. acidilactici bakterijų padermés. Tirtas jų aktyvumas prieš Aspergillus versicolor, A. terreus, A. niger, A. fumigatus, Penicillium spinulosum, $P$. viridicatum ir $P$. palitans grybus. Ryžiu poliravimo atliekos fermentuotos tradiciniu būdu, nenaudojant papildomų maisto medžiagų.

Tyrimo rezultatai patvirtino, kad ryžių poliravimo atliekos yra tinkamas substratas siekiant sukelti bakterijų priešgrybinị aktyvumą, priklausomai nuo naudotos pieno rūgšties bakterijų padermès. Analizuotos $P$. pentosaceus bakteriju padermès pasižymèjo stipriu ir vidutiniu inhibitoriniu aktyvumu prieš $P$. viridicatum ir $A$. versicolor grybus, o $P$. acidilactici padermès buvo vidutiniškai ir silpnai aktyvios prieš Aspergillus spp. grybus. Nè viena iš tirtų pieno rūgšties bakterijų nepasižymèjo priešgrybiniu aktyvumu prieš $A$. terreus ir A. niger grybus.

Reikšminiai žodžiai: Aspergillus, lactobacilli, pediococci, Penicillium, priešgrybinis aktyvumas, ryžių sẻlenos. 